DOI: 10.1136/annrheumdis-2018-eular.5662

\section{FRI0135 HAVE PREVALENCE OF JOINT SURGERY DECREASED WITH THE USE OF BIOTHERAPY IN RHEUMATOID ARTHRITIS?}

O. Saidane, M. Sellami, R. Barhoumi, A. Ben Tekaya, H. Ajlani, R. Tekaya I. Mahmoud, L. Abdelmoula. Rheumathology, Charles Nicolle Hospital, Tunis, Tunisia

Background: Biological response modifiers have greatly expanded therapeutic arsenal of rheumatoid arthritis (RA) leading to a better control of inflammation, a reduced long-term complications and a prevention of joint damage.

Objectives: Our objective was to assess the impact of use of biologics on joint surgery during RA.

Methods: This is a retrospective study including patients with RA according to American College of Rheumatology (1987) followed- over 15 years period [20002014]. We excluded patients who underwent joint surgery without direct relevance to $R A$. The significance level was set at 0.05 .

Results: A total of 500 RA patients ( 422 women and 78 men) were enrolled in this period. The mean age was 53.3 years $(21-83)$ and the mean disease duration was 12 years (2-40). Rheumatoid factor was positive in $71.4 \%$ cases. A high disease activity was noted at diagnosis with a mean disease activity score of 5.90 \pm 1 .38. The mean Health Assessment Questionnaire index was 1.62 [0.2 à 3]. All patients received at least 2 conventional disease-modifying antirheumatic drugs, one of which was methotrexate. Twenty seven per cent of RA patients (135 patients) received biologics: 35 patients received Rituximab (7\%) and 100 patients $(20 \%)$ received anti TNF $\alpha$ (infliximab, etanercept and adalimumab in $10 \%, 6.8 \%$ and $3.2 \%$ respectively). The trend curve of biologics use showed a linear increase with spikes of use in 2008, 2011 and 2014. A surgical act was considered necessary in 59 cases $(11.8 \%)$ mainly total knee arthroplasty $(56 \%)$. The mean duration between the onset of RA and surgery was 7.02 (1-33). Patients who received biologics had less joint surgery without significant association $(p=0.350)$. The joint surgery showed a decrease in the number of procedures from 2004, concomitantly with promoting biologics.

Conclusions: Our study concluded that joint surgery was less frequent in RA patients who received biologics without a significant association.

Disclosure of Interest: None declared

DOI: 10.1136/annrheumdis-2018-eular.4671

\section{FRI0136 PERSISTENCE OF MONOTHERAPY OR COMBINATION THERAPY WITH DISEASE-MODIFYING AGENTS IN PATIENTS WITH PSORIATIC ARTHRITIS IN A REAL- WORLD SETTING}

P.J. Mease ${ }^{1}$, N.A. Accortt ${ }^{2}$, S. Rebello ${ }^{3}$, C. Etzel ${ }^{3}$, R.W. Harrison ${ }^{3}$, G.A. Aras ${ }^{2}$, M. M.F. Gharaibeh ${ }^{2}$, J.D. Greenberg ${ }^{3}$, D.H. Collier ${ }^{2} .{ }^{1}$ Swedish Medical Center and University of Washington, Seattle; ${ }^{2}$ Amgen Inc., Thousand Oaks; ${ }^{3}$ Corrona LLC, Waltham, USA

Background: Until recently, treatment for moderate to severe psoriatic arthritis (PsA) mainly focused on conventional synthetic disease-modifying antirheumatic drugs (csDMARDs) and tumour necrosis factor inhibitors (TNFis). However, the persistence of TNFis alone or in combination with csDMARDs is not well understood.

Objectives: To assess real-word treatment patterns among patients with PsA receiving TNFi monotherapy, csDMARD monotherapy, or TNFi and csDMARD combination therapy.

Methods: This retrospective study utilised data from patients with PsA aged $\geq 18$ years, enrolled in the Corrona PsA registry between March 21, 2013, and July 31, 2017 , treated with a TNFi and/or csDMARD (index therapy), and with $\geq 6$ months of follow-up time. Patients were stratified by prevalent (initiation before enrollment) or incident (initiation after enrollment) therapy use; cohorts were based on index therapy: TNFi monotherapy, csDMARD monotherapy, or combination therapy. Outcomes of interest were the percentage of patients who were persistent on their index therapy or had a therapy change (discontinued, switched, or restarted) 12 months after the index visit.

Results: There were 1266 patients in this study: 1144 prevalent and 122 incident (table 1). Patient characteristics at the index date were similar among patients; however, csDMARD monotherapy patients had higher disease activity than either TNFi group. Among prevalent patients, TNFi monotherapy patients were likely to be female (59\%) and younger (51.9 years), nearly all patients had psoriasis, and BSA was similar and $\leq 5$. At month 12 , among patients with a follow-up visit within the 9-15-month window, the vast majority of prevalent patients and half of incident patients were persistent on their index therapy, and one quarter to one third of incident patients discontinued or switched therapy (table 1).

\begin{tabular}{|c|c|c|c|c|c|c|}
\hline $\begin{array}{l}\text { Characteristic at } \\
\text { index date }\end{array}$ & $\begin{array}{c}\text { Prevalent } \\
\text { TNFi mono } \\
N=421\end{array}$ & $\begin{array}{c}\text { Prevalent } \\
\text { csDMARD mono } \\
\mathrm{N}=347\end{array}$ & $\begin{array}{c}\text { Prevalent } \\
\text { combo } \\
\mathrm{N}=376\end{array}$ & $\begin{array}{c}\text { Incident } \\
\text { TNFi mono } \\
\mathrm{N}=43\end{array}$ & $\begin{array}{c}\text { Incident } \\
\text { csDMARD mono } \\
\mathrm{N}=56\end{array}$ & $\begin{array}{l}\text { Incident } \\
\text { combo } \\
\mathrm{N}=23\end{array}$ \\
\hline Sex (female), $n(\%)$ & $244(59)$ & $158(46)$ & $185(50)$ & $19(44)$ & $24(43)$ & $11(48)$ \\
\hline Age, mean (SD) & $51.9(12.3)$ & $57.7(13.3)$ & $53.9(11.3)$ & $50.7(14.0)$ & $55.8(14.1)$ & $52.3(13.5)$ \\
\hline BMI (obese), $n(\%)$ & $202(51)$ & $182(54)$ & $204(56)$ & $18(44)$ & $37(70)$ & $8(47)$ \\
\hline Current psoriasis, n & 366 (93) & 300 (90) & $312(90)$ & $38(93)$ & 49 (94) & $15(68)$ \\
\hline HAQ, mean (SD) & $0.2(0.4)$ & $0.3(0.4)$ & $0.3(0.4)$ & $0.3(0.4)$ & $0.3(0.3)$ & $0.4(0.6)$ \\
\hline CDAl, mean (SD) & $9.7(6.6)$ & $11.6(9.2)$ & $11.7(8.4)$ & $12.6(7.3)$ & $16.2(8.5)$ & $15.7(13.9)$ \\
\hline $\begin{array}{l}\text { DAS28 CRP, mean } \\
\text { (SD) }\end{array}$ & $2.4(0.9)$ & $2.7(1.0)$ & $2.8(1.0)$ & $3.0(0.7)$ & $3.4(0.8)$ & $2.8(1.4)$ \\
\hline Enthesitis, n (\%) & $74(18)$ & $52(15)$ & $75(20)$ & $14(32)$ & $8(14)$ & $3(13)$ \\
\hline Dactylitis, $n$ (\%) & $27(6)$ & $25(7)$ & $12(3)$ & $7(16)$ & $14(25)$ & $4(17)$ \\
\hline $\begin{array}{l}\text { BSA (\%), mean } \\
\text { (SD) }\end{array}$ & $4.9(8.7)$ & $4.8(9.3)$ & $5.0(11.9)$ & $6.2(8.8)$ & $5.4(8.9)$ & $1.3(2.1)$ \\
\hline $\begin{array}{l}\text { Nail psoriasis VAS, } \\
\text { mean (SD) }\end{array}$ & $5.6(12.4)$ & $8.1(22.6)$ & $7.2(14.3)$ & $11.9(18.8)$ & $5.9(15.2)$ & $10.3(23.3)$ \\
\hline $\begin{array}{l}\text { History of biologic, } n \\
\text { (\$) }\end{array}$ & $421(100)$ & 0 & $375(100)$ & $2(5)$ & 0 & 0 \\
\hline $\begin{array}{l}\text { History of } \\
\text { cSDMARD, } n(\%)\end{array}$ & $192(46)$ & $347(100)$ & $369(98)$ & $13(30)$ & 0 & $13(57)$ \\
\hline \multicolumn{7}{|c|}{ Treatment pattern, $n(\%)$} \\
\hline $\begin{array}{l}\text { Persistent, } \\
\text { n/patients with a } \\
\text { follow-up visit with in } \\
9-15 \text { month window }\end{array}$ & $233 / 251(92.8)$ & 196/225 (87.1) & 186/214 (86.9) & $13 / 26(50.0)$ & $15 / 35(42.9)$ & $8 / 15(53.3)$ \\
\hline $\begin{array}{l}\text { Time on drug } \\
\text { (mo), mean (SD) }\end{array}$ & $68.6(46.4)$ & $82.5(78.1)$ & $49.8(37.7)$ & $15.9(5.4)$ & $16.9(8.7)$ & $16.0(5.0)$ \\
\hline Discontinuation & $3(1.2)$ & $8(3.6)$ & $17(7.9)$ & $5(19.2)$ & $9(25.7)$ & $4(26.7)$ \\
\hline $\begin{array}{l}\text { Switch (to another } \\
\text { biologic) }\end{array}$ & $2(0.8)$ & $2(0.9)$ & $4(1.9)$ & $1(3.8)$ & $4(11.4)$ & $2(13.3)$ \\
\hline 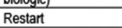 & 0 & $3(1.3)$ & $1(0.5)$ & 0 & 0 & 0 \\
\hline
\end{tabular}

Conclusions: Most patients who were prevalent on therapy at the time of enrollment in Corrona remained persistent on their therapy for 12 months in this study, while roughly half of patients initiating therapy after enrollment remained persis tent over the same period. Young, female patients were more likely to receive TNFi monotherapy; the TNFi monotherapy cohort was associated with the least disease activity. The incident group was not different from the prevalent group Although the prevalent group is more likely to have patients who responded to treatment, the data suggest that most therapy changes occur within the first yea of PsA treatment.

Disclosure of Interest: P. Mease Grant/research support from: AbbVie, Amgen, Bristol Myers Squibb, Celgene, Janssen, Lilly, Novartis, Pfizer, Sun, and UCB Consultant for: AbbVie, Amgen, Bristol Myers Squibb, Celgene, Janssen, Lilly, Novartis, Pfizer, Sun, and UCB, Speakers bureau: AbbVie, Amgen, Bristol Myers Squibb, Celgene, Genentech, Janssen, Novartis, Pfizer, and UCB, N. Accortt Shareholder of: Amgen Inc., Employee of: Amgen Inc., S. Rebello Employee of: Corrona LLC, C. Etzel Consultant for: Merck, Employee of: Corrona LLC, R. Harrison Employee of: Corrona LLC, G. Aras Shareholder of: Amgen Inc., Employee of: Amgen Inc., M. Gharaibeh Shareholder of: Amgen Inc., Employee of: Amgen Inc., J. Greenberg Shareholder of: Corrona LLC, Consultant for: Genentech, Jans sen, Novartis, Pfizer, and Eli Lilly, Employee of: Corrona LLC, D. Collier Shareholder of: Amgen Inc., Employee of: Amgen Inc. DOI: 10.1136/annrheumdis-2018-eular.1929

\section{FRI0137 EFFICACY, SAFETY AND IMMUNOGENICITY FROM WEEK 30 TO WEEK 54 IN A RANDOMISED, DOUBLE BLIND PHASE III STUDY COMPARING A PROPOSED INFLIXIMAB BIOSIMILAR (PF-06438179/GP1111) WITH REFERENCE INFLIXIMAB}

R. Alten $^{1}$, V. Tseluyko ${ }^{2}$, T. Hala $^{3}$, S. Mehmedagic ${ }^{4}$, M. Pileckyte ${ }^{5}$, E. Dokoupilová ${ }^{6}$, D. Jovic ${ }^{7}$, M. Rehman ${ }^{8}$, M. Zhang ${ }^{9}$, L. Sewell ${ }^{10}$, S. Hackley ${ }^{11}$, S. Salts ${ }^{9}$, C. Cronenberger ${ }^{12}, \mathrm{~K}$. Schumacher ${ }^{13}, \mathrm{O}$. von Richter ${ }^{13}$, B. Batko ${ }^{14}$. ${ }^{1}$ Schlosspark Klinik, Berlin, Germany; ${ }^{2}$ Kharkiv Medical Academy of Postgraduate Education, Kharkiv, Ukraine; ${ }^{3}$ Center for Clinical and Basic Research, Pardubice, Czech Republic; ${ }^{4}$ Clinical Center University of Sarajevo, Sarajevo, Bosnia and Herzegovina: ${ }^{5}$ Hospital of Lithuanian University of Health Sciences, Kaunas, Lithuania; ${ }^{6}$ Medical Plus s.r.o., Uherske Hradiste, University of Veterinary and Pharmaceutical Sciences, Brno, Czech Republic; ${ }^{7}$ University Clinical Centre of the Republic of Srpska, Banja Luka, Bosnia and Herzegovina; ${ }^{8}$ Pfizer Inc., Andover, MA; ${ }^{9}$ Pfizer Inc., La Jolla, CA; ${ }^{10}$ Pfizer Inc., Cambridge, MA, USA; ${ }^{11}$ Pfizer Ltd, Sandwich, UK; ${ }^{12}$ Pfizer Inc., Collegeville, PA, USA; ${ }^{13}$ Sandoz Biopharmaceuticals, Holzkirchen, Germany; ${ }^{14} \mathrm{~J}$. Dietl Specialist Hospital, Krakow, Poland

Background: PF-06438179/GP1111 (GP1111) is an infliximab (IFX) biosimilar in development for the treatment of immune-mediated inflammatory diseases including rheumatoid arthritis (RA). The efficacy, safety and immunogenicity of GP1111 and European reference IFX (IFX-EU) have been reported to be similar over 30 weeks (Wks)

Objectives: To evaluate the efficacy, safety and immunogenicity of GP1111 and IFX-EU with longer-term treatment, and after treatment transition from IFX-EU to GP1111.

Methods: A randomised, double-blind, parallel-group study compared GP1111 with IFX-EU in biologic-naïve, adult patients with moderate-to-severe active RA on a stable dose of methotrexate (MTX). Patients were randomised (1:1) to GP1111 or IFX-EU ( $3 \mathrm{mg} / \mathrm{kg}$ IV at Wks $0,2,6$, and then every $8 \mathrm{wks}$, with one dose escalation to $5 \mathrm{mg} / \mathrm{kg}$ allowed at or after Wk 14 for inadequate responders) 